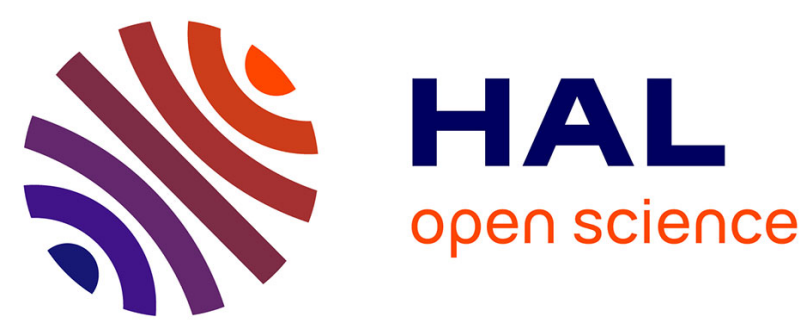

\title{
Adsorption at cell surface and cellular uptake of silica nanoparticles with different surface chemical functionalizations: impact on cytotoxicity
}

Andréa Kurtz-Chalot, Jean-Philippe Klein, Jérémie Pourchez, Delphine Boudard, Valérie Bin, G. B. Alcantara, Matteo Martini, Michèle Cottier, Valérie Forest

\section{To cite this version:}

Andréa Kurtz-Chalot, Jean-Philippe Klein, Jérémie Pourchez, Delphine Boudard, Valérie Bin, et al.. Adsorption at cell surface and cellular uptake of silica nanoparticles with different surface chemical functionalizations: impact on cytotoxicity. Journal of Nanoparticle Research, 2014, 16 (11), pp.2738. 10.1007/s11051-014-2738-y . hal-01215292

\author{
HAL Id: hal-01215292 \\ https://hal.science/hal-01215292
}

Submitted on 15 Oct 2015

HAL is a multi-disciplinary open access archive for the deposit and dissemination of scientific research documents, whether they are published or not. The documents may come from teaching and research institutions in France or abroad, or from public or private research centers.
L'archive ouverte pluridisciplinaire HAL, est destinée au dépôt et à la diffusion de documents scientifiques de niveau recherche, publiés ou non, émanant des établissements d'enseignement et de recherche français ou étrangers, des laboratoires publics ou privés. 


\section{Adsorption at cell surface and cellular uptake of silica nanoparticles with different surface chemical functionalizations: impact on cytotoxicity}

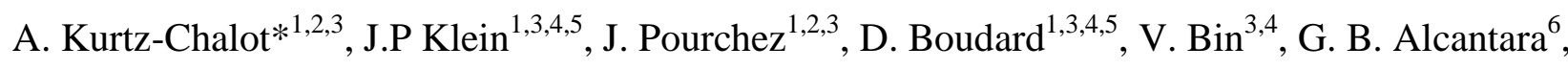
M. Martini ${ }^{7}$, M. Cottier ${ }^{1,3,4,5}$ and V. Forest ${ }^{1,2,3}$.

*Corresponding author: kurtz-chalot@emse.fr (Tel: +33(0) 477421494 Fax: +33(0) 47749 96 94)

1 LINA Laboratoire Interdisciplinaire d'étude des Nanoparticules Aérosolisées (EA 4624) Faculté de Médecine Jacques Lisfranc, 15 rue Ambroise Paré, 42023 Saint-Étienne Cedex 2, France.

2 École Nationale Supérieure des Mines de Saint-Etienne, 158 cours Fauriel, CS62362, 42023 Saint-Etienne cedex 2, France.

3 SFR IFRESIS, UFR de Médecine, 15 rue Ambroise Paré, 42023 Saint-Etienne cedex 2, France.

4 Université Jean Monnet, Saint-Etienne, France.

5 CHU, Saint-Etienne, France.

6 PRES Lyon, Centre de Microscopie Confocale Multiphotonique, INSA de Lyon, Bâtiment Blaise Pascal 7 avenue Jean Capelle, 69621 Villeurbanne Cedex, France.

7 ILM, Institut Lumière Matière, UMR 5603 CNRS, Université Claude Bernard Lyon 1, Bâtiment Kastler 10 rue Ada Byron, 69622 Villeurbanne cedex, France. 


\begin{abstract}
Silica nanoparticles are particularly interesting for medical applications because of the high inertness and chemical stability of silica material. However, at the nanoscale their innocuousness must be carefully verified before clinical use. The aim of this study was to investigate the in vitro biological toxicity of silica nanoparticles depending on their surface chemical functionalization. To that purpose, three kinds of $50 \mathrm{~nm}$ fluorescent silica-based nanoparticles were synthesized: 1) sterically stabilized silica nanoparticles coated with neutral polyethylene glycol (PEG) molecules, 2) positively charged silica nanoparticles coated with amine groups and 3) negatively charged silica nanoparticles coated with carboxylic acid groups. RAW 264.7 murine macrophages were incubated for 20 hours with each kind of nanoparticles. Their cellular uptake and adsorption at the cell membrane were assessed by a fluorimetric assay and cellular responses were evaluated in terms of cytotoxicity, pro-inflammatory factor production and oxidative stress. Results showed that the highly positive charged nanoparticle, were the most adsorbed at cell surface and triggered more cytotoxicity than other nanoparticles types. To conclude, this study clearly demonstrated that silica nanoparticles surface functionalization represents a key parameter in their cellular uptake and biological toxicity.
\end{abstract}

Key words: Silica nanoparticles, macrophages, surface functionalization, uptake, proinflammatory effect, cytotoxicity. 


\section{INTRODUCTION}

Because amorphous silica is characterized by chemical stability and inertness independently of $\mathrm{pH}$ and temperature, it is used for biomedical applications like dental fillings, gel-catheters, biosensors and bioengineering of bone (Auffinger et al. 2013; Colilla et al. 2008; Vallet-Regi and Balas 2008). Recently amorphous silica has encompassed the emerging field of nanotechnology (as anti-caking agents in food, as nano-abrasive in cosmetics, as reinforcing fillers in rubber...)(Napierska et al. 2010). It is also of particular interest for nanomedicine because of the advantages silane chemistry offers (Slowing et al. 2008; Mignot et al. 2013). Indeed, the surface of silica nanoparticles can be modified with chemical functional groups like addition of specific antibodies or fluorescent labels for specific drug delivery (targeting of cancer cells) or specific diagnosis (tumor labeling)(Chandolu and Dass 2013). As an example dye-doped fluorescent (Cyanine-5) silica nanoparticles ( $8 \mathrm{~nm}$ in diameter), known as "Cornell dots", have been approved in 2011 by the US Food and Drug Administration (FDA) for human stage I molecular imaging of cancer (Benezra et al. 2011). Those confirm the importance of future clinical potentials of silica-based nanoparticles as effective and specific medical tools. However, those objects exhibiting novel and significantly improved physical and chemical properties due to the nanoscale, consequently exhibit a novel biological activity in human body (Lidén 2011; Riehemann et al. 2009). This is why current in vivo and in vitro researches are ongoing for a better knowledge of nanoparticles fate and to provide safer uses (Seaton and Donaldson 2012).

Nanoparticles whose size is close to that of cellular components, may interact specifically with cells (Huang et al. 2005). They can adhere to the cell membrane or be entirely engulfed by different pathways, especially by macrophage cells due to their phagocytic capacity (Leclerc et al. 2012). In order to better understand these interactions, fluorescent labeled nanoparticles may 
be used and tracked through the cells. Literature highlights that the uptake of nanoparticles (pathway and rate) strongly depends on cell type (Sohaebuddin et al. 2010) and on the nanoparticle physico-chemical features (Musyanovych et al. 2011; Chung et al. 2007; Hu et al. 2007). It is well admitted that these latter may play a role in nanoparticle cytotoxicity (Greish et al. 2011; Yu et al. 2011; Chung et al. 2007), and several parameters to take into consideration to engineer safer nanoparticles were defined by ISO TS/13014 (2012a) ("safer by design" approach): size, shape, surface functionalization, state of agglomeration and agregation, composition, solubility, dispersibility, specific surface area, density of surface groups and surface chemistry (Frohlich 2012; Duffin et al. 2007; Albanese et al. 2012). This study will focus on nanoparticle surface functionalization.

Greish et al. already demonstrated that surface charge of silica nanoparticles (coated with amine or hydroxyl groups) significantly influenced their biodistribution in mice. But toxicity evaluated by animal weight loss did not seem to be influenced by the surface charge of the nanoparticles (Greish et al. 2011). Landsiedel et al. showed that during short-term inhalation of silica particles (coated with amine or PEG) by rats, surface modifications changed the toxicity of the core material in terms of cytokine production in broncho-alveolar lavage fluid (BALF) (Landsiedel et al. 2014). In a complementary way, in vitro assays are informative on the direct interactions between immune cells and nanoparticles. For example, Nabeshi et al., incubated unmodified or modified (with amine or hydroxyl groups) silica nanoparticles with murine macrophages and revealed that the cell proliferation decreased when cells were incubated with unmodified silica nanoparticles; they concluded that the surface functionalization by both amino and hydroxyl groups decreased their toxicity (Nabeshi et al. 2011). In the same way, Lankoff et al., showed that, in contrast to unmodified silica nanoparticle, positively charged nanoparticles with aminopropyl/vinyl coating expressed no cytotoxicity on lymphocytes (cell viability, 
apoptosis/necrosis...) (Lankoff et al. 2013). Thus, nanoparticle coating may allow safer nanomedicine and number of studies point out the importance of surface functionalization of nanoparticles on their interaction with cells and biological responses (Dausend et al. 2008; El Badawy et al. 2011; Mura et al. 2011).

However, one of the particularities of nanoparticles to consider is that they are changing objects. Their "biological identity" evolves in biological media over time (Faunce et al. 2008; Dell'Orco et al. 2010). Proteins are adsorbed and desorbed from the nanoparticle surface. This so called "corona" becomes the first element of the nanomaterial in contact with the cells. It is difficult to determine precisely, therefore, it is important to characterize again nanoparticles in culture media in terms of surface charge and size (Walkey and Chan 2012).

The aim of the present study was to investigate the relationship between surface functionalization of silica nanoparticles and their cellular uptake and toxicity. For that purpose, three kinds of 50 $\mathrm{nm}$ fluorescent (fluorescein isothiocyanate - FITC) silica-based nanoparticles were synthetized at the laboratory scale: 1) sterically stabilized nanoparticles coated with neutral polyethylene glycol (PEG) molecules, 2) positively charged nanoparticles coated with amine groups and 3) negatively charged nanoparticles coated with carboxylic acid groups. Nanoparticles were incubated with murine macrophages as these cells represent the first line of defense against inhaled exogenous elements and are an in vitro reference model in nanotoxicology. Cellular uptake and adsorption at cell membrane was then assessed by fluorimetry and the cellular response was evaluated in terms of cytotoxicity: loss of cell membrane integrity (determined by the Lactate DeHydrogenase (LDH) assay), pro-inflammatory effect (TNF- $\alpha$ production) and oxidative stress (Reactive Oxygen Species (ROS) generation).

\section{MATERIALS AND METHODS}




\section{Nanoparticles synthesis}

Silica-based nanoparticles, called NP, were prepared according to a previous method developed by Martini et al. (Martini et al. 2009). The fluorescence of FITC was increased by the gold core by Förster resonance energy homo-transfer (homo-FRET) non radiative.

Five kinds of nanoparticles were produced and referred according to charges profile of their surface chemical groups. Sterically stabilized were referred to as $\mathrm{NP}(0)$, positively charge stabilized nanoparticles were coated with a variable amount of amine groups: $\mathrm{NP}(++)$ and $\mathrm{NP}(+)$, negatively charge stabilized nanoparticles with a variable amount of carboxylic acid groups: NP(-) and NP(-).

The water/oil (W/O) microemulsion procedure was considered the best way to produce homogeneous and reproducible core-shell samples for systematic biological assays. Indeed, each reverse micelle (aqueous droplets sized $\sim 10 \mathrm{~nm}$ ) acts as template for the controlled-growth of core-shell structures. Quaternary W/O microemulsions were prepared by mixing Triton X-100 (surfactant), n-hexanol (co-surfactant) and cyclohexane (oil), followed by sequential additions of specific polar-like precursors. An inclusion of gold clusters at the center of each particle was obtained by the reduction of gold salt in presence of ligands and $\mathrm{NaBH}_{4}$. The formation of polysiloxane matrix arised from the base-catalyzed hydrolysis and condensation of two silica precursors: $92 \% \mathrm{w}$ TEOS (tetraethoxysilane) and $8 \% \mathrm{w}$ dye conjugated-APTES ((3aminopropyl)triethoxysilane). APTES conjugates ensured a covalent bonding of dyes (Fluorescein molecules FITC) and their random distribution within nanoparticles. The colloidal stabilization was then achieved by the final addition of specific silane precursors that leads the specific surface charge for further biological assays (Table 1). In order to obtain an average number of negative charge per surface unit equal to $2 / \mathrm{nm}^{2}(\mathrm{NP}(--))$, a controlled amount of $3-$ (Triethoxysilyl)propylsuccinic anhydride ( $\mathrm{Si}-\mathrm{COOH})$ has been added, whereas for the positive 
charged nanoparticles (NP(++)), N-(2-Aminoethyl)-3-aminopropylmethyldimethoxysilane was chosen as precursor. Neutral particles, NP(0), exhibit $1 / \mathrm{nm}^{2} \quad \mathrm{~N}-(3-$ Triethoxysilylpropyl)gluconamide molecules as well as $1 / \mathrm{nm}^{2} \mathrm{mPEG}$-silane $2 \mathrm{kDa}$ at their surface, giving an additional steric contribution to the colloidal stability. Thereafter, all solvents were eliminated by the addition of acetone followed by several cycles of vortexing and centrifuging. Unreacted dyes and precursors were removed by ultrafiltration using $300 \mathrm{kDa}$ PES membranes (with a purification rate higher than 108). Particles were dispersed in aqueous solution $(2 \mathrm{~g} / \mathrm{L})$ and stored at $4^{\circ} \mathrm{C}$.

\section{Physico-chemical characterization of nanoparticles}

The detailed structural and morphological characterization of the samples was carried out by Scanning Electron Microscopy (SEM) using an ESEM XL30-FEI microscope equipped with a thermal field emission gun (FEG) and Transmission Electron Microscopy (TEM) using a Philips CM200 microscope. The samples were prepared by depositing a drop of diluted colloidal solution onto a carbon grid (200 meshes) and allowing the solvent to evaporate at room temperature. The direct measurement of hydrodynamic size as well as zeta potential was performed by Dynamic Light Scattering (Zetasizer NanoZS, Malvern). The monoexponential correlation function obtained allowed determining the hydrodynamic size, and zeta potential values for nanoparticles dispersed at dose of $100 \mu \mathrm{g} / \mathrm{ml}$ in MilliQ water or cell culture medium Dulbecco's modified Eagle's medium (DMEM, Invitrogen, Cergy Pontoise, France) supplemented with $10 \%$ of fetal calf serum (Invitrogen) and 1\% penicillin-streptomycin (penicillin 10,000 units/ml, streptomycin 10 mg/ml; Sigma-Aldrich, Saint-Quentin Fallavier, France) (DMEMc). Measurements were performed in triplicate at room temperature of $25^{\circ} \mathrm{C}$. Refractive index (RI) and viscosity values were applied for water and cell culture medium ( $1.3 \mathrm{mPa} \cdot \mathrm{s}$ viscosity for culture medium and 0.8 $\mathrm{mPa} \cdot \mathrm{s}$ viscosity for water). 


\section{Cell culture}

RAW 264.7 cell line derived from mice peritoneal macrophages transformed by the Abelson murine leukemia virus and was provided by ATCC Cell Biology Collection (Promochem, LGC, Molsheim, France). Cells were cultured in DMEMc at $37^{\circ} \mathrm{C}$ and under a 5\% carbon dioxide humidified atmosphere.

\section{Cells/nanoparticles contacts}

For cell morphology analysis, RAW 264.7 cells were seeded in a 12-well plate (1 million cells per well) and were allowed to attach for $4 \mathrm{~h}$. Cells were incubated with 50 or $300 \mu \mathrm{g} / \mathrm{ml}$ of nanoparticles suspension for $20 \mathrm{~h}$. Cells were harvested and $100 \mu \mathrm{l}$ of cell suspension were used to prepare cytospin after cytocentrifugation (cytospin IV Shandon, Thermo electric, France). Cells were stained by May-Grünwald Giemsa method and observed under camera microscope (NISelements, Nikon, France). A semi-quantitative analysis was conducted after the observation of 100 cells in order to determine the amount of activated macrophages.

Because in vitro experimental researches are not normalized in term of nanoparticles dose (Bhattacharjee et al. 2010; Yu et al. 2011; DeLoid et al. 2014) and a significant cell response is needed to compare the effects of the differently designed nanoparticles, the dose range was chosen after a preliminary study on a logarithmic scale as 5,50 and $300 \mu \mathrm{g} / \mathrm{ml}$.

For cellular uptake and cytotoxicity assays, macrophages were seeded in 96-well plates (100 000 cells in $200 \mu \mathrm{l}$ of medium per well) and were allowed to adhere for $4 \mathrm{~h}$. Nanoparticles were diluted in cell culture medium to reach the following final concentrations: 5, 50, and $300 \mu \mathrm{g}$ $\mathrm{NP} / \mathrm{ml}$. Nanoparticles were added to cells and incubation lasted 20h.

\section{Cellular uptake assessment}


Nanoparticle uptake was quantified using a fluorometer (Fluoroskan Ascent, Thermolabsystems, France). FITC labeled nanoparticles have an excitation peak at $485 \mathrm{~nm}$ and an emission peak at $538 \mathrm{~nm}$ (green fluorescence) with a large spectrum. Total nanoparticles fluorescence was measured at each dose in order to obtain a calibration curve. Then the fluorescence of nanoparticles in supernatant, adsorbed to cell membrane and internalized by cells were discriminated by a "trypan blue quenching" (TB) method previously developed by Leclerc et al. from flow cytometry techniques (Van Amersfoort and Van Strijp 1994; Nuutila and Lilius 2005; Leclerc et al. 2010). In addition to its principal function as an exclusion dye of dead cells, TB is known for its ability to "turn off" the green fluorescence emitted by FITC labeled particles outside the cells (Leclerc et al. 2012). This process allowed us to distinguish internalized nanoparticles from those just adhering to the plasma membrane (Gratton et al. 2008). After 20 hours of contact between nanoparticles and macrophages, the fluorescence of nanoparticles remained in cell supernatant was measured as well as the fluorescence of nanoparticles adsorbed at the cell surface and the fluorescence of the nanoparticles uptaken by cells. For each condition, nanoparticles fluorescence was measured independently. Control wells without nanoparticles were used to assess the autofluorescence of cells in culture medium.

Cellular uptake of nanoparticles was also observed using transmission electron microscopy (TEM). TEM images were obtained using a JEOL 2010F FEG microscope at a $200 \mathrm{kV}$ accelerating voltage. Samples were prepared by dropping sample suspension on a carbon-coated holey film supported on a $3 \mathrm{~mm}$ mesh copper grid.

\section{Cytotoxicity assays}

\section{Membrane integrity}

The release in the cell culture supernatant of the cytoplasmic lactate dehydrogenase (LDH) from cells with damaged membranes was assessed using the CytoTox-96 ${ }^{\mathrm{TM}}$ Homogeneous Membrane 
Integrity Assay (Promega, Charbonnières les bains, France) according to the manufacturer's instructions. The optical density of the samples was determined using a microplate reader (Multiskan RC; Thermolabsystems, Helsinki, Finland) set to $450 \mathrm{~nm}$. The activity of the released LDH was reported to that of total cellular LDH (measured after control cells lysis) and was expressed as a percent of the control lysed cells. Each experiment was repeated independently three times for each sample.

As nanoparticles could potentially interfere with the different kit reagents, it was verified that there was no artifact in the measure. To that purpose, nanoparticles were incubated with cells for $20 \mathrm{~h}$ and the LDH assay was performed. Then the samples were lyzed and the LDH assay was carried out again. No significant difference was detected between lysed cells incubated with or without nanoparticles, showing the reliability of the assay.

\section{Pro-inflammatory effect}

After incubation with nanoparticles, the production of TNF- $\alpha$ was assessed in the supernatant using a commercial ELISA Kit (Quantikine ${ }^{\circledR}$ Mouse TNF- $\alpha$ Immunoassay; R\&D Systems, Lille, France) according to the manufacturer's instructions. The optical density of each sample was determined using a microplate reader (Multiskan RC; Thermolabsystems, Helsinki, Finland) set to $450 \mathrm{~nm}$. A standard curve was established, and results were expressed in picograms per milliliter of TNF- $\alpha$. Each experiment was repeated independently three times for each sample and included controls: cells alone (negative control) and DQ12 quartz (toxicological positive control) (Bruch et al. 2004; Fubini et al., 2004).

In order to verify the absence of any artifact caused by the presence of the nanoparticles, the concentration of a standard solution of TNF- $\alpha$ was assessed with the ELISA test (in cell free conditions). Particles were then added to this solution and the TNF- $\alpha$ concentration was assessed 
again. No significant difference in TNF- $\alpha$ concentration was observed between the sample with and the sample without nanoparticles indicating that no artifacts occurred in the assessment due to the nanoparticles.

\section{Oxidative stress}

A large array of reactive oxygen species (ROS) activity can be assessed with the OxiSelect ${ }^{\mathrm{TM}}$ ROS Assay Kit (Euromedex, Mundolsheim, France). The assay uses the conversion of a nonfluorescent substrate, 2.7'-dichlorodihydrofluorescein diacetate that can easily diffuse through cell membranes and be converted into a fluorogenic molecule $2^{\prime} .7^{\prime}$-dichlorodihydrofluorescein (DCF) in presence of ROS and which fluorescence is proportional to total ROS level. DCF production was detected using a Fluoroskan Ascent fluorometer (Thermolabsystems) using excitation and emission wavelengths of 480 and $530 \mathrm{~nm}$ respectively, and the generation of ROS was expressed as nanomolar. Each experiment was repeated independently three times for each sample.

In order to verify that no artifact was induced by the nanoparticles, a standard solution of DCFHDA was assessed either in presence or in absence of nanoparticles. No significant difference was detected between the samples indicating that no artifacts were involved.

\section{Statistical analysis}

Analysis and graphics were performed on Prism 5.0 software (GraphPad, San Diego, CA). Significance was established with two-way-ANOVA test (compared to negative control: cells alone) or one-way-ANOVA (compared to each other) and data considered significant with $p<$ 0.05 are marked with an asterisk $(*)$ sign. Each data point represents the mean of three independent experiments $(n=3)$ and is presented with the arithmetic standard error means $( \pm$ SEM). 


\section{RESULTS}

\section{Nanoparticles characterization}

In Fig.1, the spherical shape was clearly observed by SEM. The dark gold core and the grey silica shell can easily be observed using TEM. Geometric diameters were measured from electron microscopy. Hydrodynamic diameters and zeta potential were measured using DLS. These data are reported in Table 1.

In water and for each type of nanoparticles, the hydrodynamic diameter was correlated with the geometric diameter, whereas in DMEMc it was significantly increased. Similarly, zeta-potentials of the five kinds of nanoparticles were distinct in water but in DMEMc all zeta-potentials became negative, with the most important decrease of surface charges observed for the nanoparticles exhibiting the highest initial charges: $\mathrm{NP}(--)$ and $\mathrm{NP}(++)$.

\section{Cellular uptake}

Cellular uptake was then quantified using a quantitative assessment by fluorimetry as reported in Fig.2. The amounts of nanoparticles in supernatant, adsorbed at cell membrane or uptaken were determined. It clearly appeared that nanoparticles mainly remained in the supernatant whatever the surface functionalization. Moreover uptake and adsorption were found to be dose-dependent irrespective of the nanoparticle type.

Therefore, at the same dose, the amount of nanoparticles uptaken and adsorbed at the cell surface was surface charge-dependent: the uptake was more important for the nanoparticles exhibiting negative charges: $\mathrm{NP}(--), \mathrm{NP}(-)$ or neutral charges $\mathrm{NP}(0)$. Almost no uptake was detected for positively charged $\mathrm{NP}(+)$ and $\mathrm{NP}(++)$. In contrast, a higher adsorption at cell membrane was observed for the positively charged nanoparticles $\mathrm{NP}(++)$ and then $\mathrm{NP}(+)$. 
Cellular uptake was also investigated by TEM. Similar patterns of cellular uptake were observed for the different types of nanoparticles. An illustration is given in Fig. 3 for control cells and cells incubated with $300 \mu \mathrm{g} / \mathrm{ml}$ of $\mathrm{NP}(0)$ or $\mathrm{NP}(++)$. The observations were in good accordance with the quantitative uptake presented in Fig.2 except for $\mathrm{NP}(++)$. Indeed, no uptake of $\mathrm{NP}(++)$ was detected by fluorescence even at the high dose of $300 \mu \mathrm{g} / \mathrm{ml}$ while uptake of $\mathrm{NP}(++)$ by microscopy was actually observed.

\section{Cytotoxicity}

\section{Cell morphology}

Fig.4 shows the global morphology of cells after a $20 \mathrm{~h}$ contact with $\mathrm{NP}(0)$ and the nanoparticles exhibiting the highest charges: $\mathrm{NP}(--)$ and $\mathrm{NP}(++)$. Two concentrations of nanoparticles were tested: 50 and $300 \mu \mathrm{g} / \mathrm{ml}$. At low dose, large vacuoles clearly appeared in cytoplasm of cells in contact with $\mathrm{NP}(++)$ suggesting the macrophages activation (Luzio et al. 2003). At high dose, the amount of vacuoles was increased in cells incubated with each type of nanoparticles. Similarly, cells with a lysed membrane and condensed nucleus, called "ghost" cells, were clearly identified demonstrating advanced cytotoxicity, especially with $\mathrm{NP}(++)$.

Table 2 is a semi-quantification of the cell morphology evolution. It took a high dose of $\mathrm{NP}(--)$ and $\mathrm{NP}(0)$ to activate macrophages without inducing a significant mortality (5 and 16\% of ghost cells respectively). On the contrary, at low dose $\mathrm{NP}(++)$ activated much more macrophages (79\%) and provided a high level of mortality at high dose (77\% of ghost cells) suggesting that $\mathrm{NP}(++)$ were the most cytotoxic nanoparticles.

\section{Membrane integrity}

Quantitative results for membrane integrity assay are shown in Fig.5. The LDH release triggered by $\mathrm{NP}(-), \mathrm{NP}(0)$ and $\mathrm{NP}(+)$ was not significantly different from that of control cells (incubated without nanoparticles). On the opposite, $\mathrm{NP}(++)$ were found to be cytotoxic at doses as low as 5 
$\mu \mathrm{g} / \mathrm{ml}$ and $\mathrm{NP}(--)$ became significantly cytotoxic at the highest concentration $(300 \mu \mathrm{g} / \mathrm{ml})$. A dose-dependent effect appeared for those two types of nanoparticles.

\section{TNF-a pro-inflammatory production}

Pro-inflammatory effects of the nanoparticles were determined by the TNF- $\alpha$ assay. Results are shown in Fig.6. Basal level of TNF- $\alpha$ production was increased by the presence of nanoparticles for the five types of nanoparticles only at high doses. The inflammatory effect was dosedependent and nanoparticles biological effect exceeded the positive control DQ12 signal at high doses of $300 \mu \mathrm{g} / \mathrm{ml}$. $\mathrm{NP}(++)$ induced the highest pro-inflammatory signal from doses of 50 $\mu \mathrm{g} / \mathrm{ml}$.

\section{Oxidative stress}

No significant oxidative stress was detected when cells were incubated with the different types of nanoparticles. Relative quantification of ROS probe DCF in cells in contact with each kind of nanoparticles was around $45 \mathrm{nM}$ (data not shown) and was not statistically different from $48 \mathrm{nM}$ detected for control cells.

\section{Discussion}

This study aimed at understanding the relationship between the surface chemical functionalization of $50 \mathrm{~nm}$ silica-based nanoparticles, their toxicity and ability to be uptaken by cells. A series of fluorescent nanoparticles constituted by a polysiloxane-coated gold cluster that encapsulates FITC were prepared by a microemulsion method. SEM analysis confirmed the presence of well-organized film of nanoparticles with spherical shape (Fig.1(A)). TEM images revealed gold/polysiloxane nanoparticles with an average size of $54 \mathrm{~nm}$ and a standard deviation value less than $2 \mathrm{~nm}$ (Fig.1(B)). A thorough physico-chemical characterization of the 
nanoparticles was carried out in water and in cell culture medium DMEMc by dynamic light scattering instrument. It was observed that the hydrodynamic diameter and the zeta potential of the nanoparticles exhibiting the highest charges (i.e. $\mathrm{NP}(--)$ and $\mathrm{NP}(++)$ ) were the most evolving in DMEMc. Both diameters became superior to $100 \mathrm{~nm}$ and zeta potentials decreased to about $95 \mathrm{mV}$ due to the buffered culture medium. Those changes between water and culture medium are very likely due to the adsorption of proteins from the culture medium at the nanoparticles surface forming the so-called "corona" (Cedervall et al. 2007). Therefore, chemical groups initially grafted onto the nanoparticle surface are hidden by proteins and nanoparticle surface charge is rather related to the nature of the adsorbed proteins. Thus, initially positively charged and initially negatively charged nanoparticles may exhibit a similar global negative zeta potential in cell culture medium. Moreover it does not imply an equivalent protein corona (Lundqvist et al. 2008; Tenzer et al. 2013). This difference in protein corona composition may consequently mediate different interactions with cells. And indeed, we observed that initially positively charged nanoparticle were less uptaken than initially negatively charged nanoparticles (Fig. 2). The initial nanoparticle charge can thus indirectly influence the interactions with cells through the chemical nature of the corona. Qiu et al. showed as well that proteins quickly adsorbed onto gold nanorods of different surfaces and turned the nanoparticles surface charges negatively. When incubated with a human breast adenocarcinoma cell line (MCF-7) it resulted that surface charge of nanoparticles may not directly affect the cellular uptake, but the amount of serum proteins adsorbed on the nanoparticles was positively correlated with the capacity of nanoparticles to enter into cells (Qiu et al. 2010).

Hydrodynamic diameter and zeta potential of $\mathrm{NP}(-)$ and $\mathrm{NP}(+)$ did not evolve much certainly due to a poor density of charged surface groups. Similarly, NP(0) coated with PEG did not 
significantly vary in the transition from water to DMEMc. This was consistent with literature data as it is admitted that «PEGylation », i.e. the grafting of linear chains of PEG at nanomaterial surface, allows reducing protein adsorption by blocking protein-binding sites and creating a steric hindrance (Walkey et al. 2012).

Nanoparticles were incubated with macrophages and their uptake was assessed before the evaluation of their in vitro toxicity. Concerning the uptake of $\mathrm{NP}(++)$, results from TEM and fluorimetry analyses seemed contradictory at first sight. However it should be kept in mind that these two techniques were performed with a different aim and can hardly be directly compared. Indeed, TEM images were used to verify the presence (or not) of nanoparticles in cells (Gratton et al. 2008). They also allowed obtaining information on the subcellular localization of nanoparticles within cells. Indeed, TEM visualization confirmed the cellular uptake of the five kinds of studied nanoparticles with an accurate localization in vacuoles (Fig.3). However, this method, takes into account only survival cells and was not representative to all cells initially in contact with nanoparticles. Besides, this technique is essentially qualitative and does not permit to rigorously quantify the number of nanoparticles uptaken. Moreover, the preparation of the samples and the technique itself are too heavy to perform enough analyses to get statistically relevant results. On the opposite, fluorimetry was used to obtain quantitative data and to compare the capacity of different types of nanoparticles to be uptaken by cells. Furthermore, this method, combined with the use of the Trypan Blue dye, allows to distinguish FITC fluorescent nanoparticles uptaken from nanoparticles adsorbed (Nuutila and Lilius 2005) at the cell membrane by quenching the fluorescence of nanoparticles outside cells. Those data were expressed as means of detected fluorescence per cell related to the total amount of previously seeded cells in each well. It should be noted that FITC fluorescence might be altered in 
endocytosis vesicles because of their high acidity (Munkholm et al. 1990; Ohkuma and Poole 1978). Thus, the number of nanoparticles per cell could be slightly underestimated but it allowed to compare the ability of each type of nanoparticles to be uptaken by cells.

Interestingly, $\mathrm{NP}(++)$ was the kind of nanoparticles the most adsorbed at the cell surface,. Many authors already reported that high adsorption of positive nanoparticles may be related to electrostatic interactions with the negatively charged cell surface (Ge et al. 2009; El Badawy et al. 2011). But, as previously mentioned, initially positively charged nanoparticles exhibited a negative zeta potential in cell culture medium due to the formation of a protein corona. This suggests that the assumption of a high adhesion of positive nanoparticles to cell membrane through electrostatic interactions should be revisited in favor of an indirect effect due to the protein corona. These interactions need further investigations to be better understood.

Similarly, it is commonly accepted in the literature that positively charged nanoparticles are more uptaken than other kinds of nanoparticles (Chung et al. 2007; Yue et al. 2011). For instance Guarnieri et al. reported that (25 to $115 \mathrm{~nm}$ ) particles surface functionalized with positively charged groups were more uptaken than those functionalized with negatively charged groups (Guarnieri et al. 2014). Likewise, Rancan et al. reported that the functionalization of the particle surface with positively charged groups enhanced the in vitro cellular uptake (Rancan et al. 2012). These data appear in contradiction with our results, showing that $\mathrm{NP}(++)$ and $\mathrm{NP}(+)$ were less uptaken than $\mathrm{NP}(0)$ or $\mathrm{NP}(--)$ and $\mathrm{NP}(-)$. This could be due to a difference of functionalization in group types and density as suggested by Graf et al. Indeed, they discussed that one type of (55 $\mathrm{nm}$ ) positively charged particle (AHAPS) was easily internalized by macrophages, while another type of positively charged particle (short alkyl chain aminosilanes) was uptaken by cells in a lower amount (Graf et al. 2012). 
These studies also established a link between a low uptake and particles aggregation. In particular, Guarnieri et al. demonstrated that the fact that positive nanoparticles were more internalized than negative nanoparticles was contrasted by the tendency of particles to form agglomerates leading to lower internalization efficiency. This could explain our observations. In fact, among the DLS data, size measurements showed several peaks corresponding to different hydrodynamic diameters were represented, which is a characteristic of a polydisperse suspension. For example, for the sample of $\mathrm{NP}(0)$ in DMEMc, peaks of $10 \mathrm{~nm}, 88 \mathrm{~nm}$ and $450 \mathrm{~nm}$ in diameter were observed. For each sample, the assumption was made that the peak with the closest value to the nanoparticle geometric diameter (measured on TEM images) corresponded to the nanoparticle population and indicated its hydrodynamic diameter. For example, NP(0) hydrodynamic diameter was determined as being $88 \mathrm{~nm}$ (the $10 \mathrm{~nm}$ population was certainly debris and the $450 \mathrm{~nm}$ population was certainly aggregates of proteins and nanoparticles). Moreover, the DLS data indicated for each peak a distribution rate, which was assumed to be equivalent to the percentage of monodispersed nanoparticles. This leaded to estimate that $5 \%$ of $\mathrm{NP}(++)$ were monodispersed against 40 and $30 \%$ for $\mathrm{NP}(0)$ and $\mathrm{NP}(--)$ respectively. Therefore, $\mathrm{NP}(++)$ were less internalized than $\mathrm{NP}(0)$ and $\mathrm{NP}(--)$ possibly in relation to their agglomeration state.

Discrepancies between our results and that of Guanieri et al. can also be explained by the fact that experiments were carried out using different cell models. This hypothesis is supported by Chung et al. study (Chung et al. 2007) where the surface charge of mesoporous silica nanoparticles varied by the degree of surface modification with N-trimethoxysilylpropyl-N,N,Ntrimethylammonium chloride and their uptake was detected by flow cytometry in different cell lines (3T3-L1 and human mesenchymal stem cells). Results showed that particle uptake by 
human mesenchymal stem cells can be regulated by a threshold of positive surface charge but also implied that the modulation of surface charge on nanoparticles uptake was specific to cell type.

Nevertheless, those quantitative results may be differently interpreted considering morphological May-Grünwald Giemsa microscopic images (Fig.4). Taken together, fluorescent uptake quantification and morphology images of cells in contact with $\mathrm{NP}(++)$ showed that $\mathrm{NP}(++)$ exhibited the lowest uptake and the highest cytotoxicity. Considering those results, two assumptions could be made: (1) A simple contact between nanoparticles and the cell membrane is sufficient to induce the cytotoxicity. In other words, $\mathrm{NP}(++)$ do not need to be uptaken to be cytotoxic. (2) The low amount of internalized $\mathrm{NP}(++)$ might not necessarily be related to a lower uptake but could be due to an important release of the nanoparticles outside of the cell in relation to their high cytotoxicity, precluding the detection of previously engulfed nanoparticles and a very important ghost morphology. Consistent with this hypothesis is the fact that $\mathrm{NP}(++)$ induced a significant loss of membrane integrity ( $\mathrm{LDH}$ release) from the lowest doses (5 and $50 \mu \mathrm{g} / \mathrm{ml})$ and a significant pro-inflammatory effect from low dose $(50 \mu \mathrm{g} / \mathrm{ml})$ while no cytotoxicity is detected for other nanoparticles types. Moreover, this second assumption could explain contradictory results obtained from TEM and fluorimetry analyses for $\mathrm{NP}(++)$. As a mater of fact, TEM images mainly showed intracellular nanoparticles in observed cells while fluorimetry quantification method showed very low content of internalized $\mathrm{NP}(++)$. If we consider that $\mathrm{NP}(++)$ induce a high level of loss of membrane integrity that lead to a high release of $\mathrm{NP}(++)$, we deduced that only the few surviving cells and cells containing $\mathrm{NP}(++)$ were not representative of the high amount of cells put in contact with nanoparticles. Besides, the relative lower detection limit of the fluorimetry method does not allowed to detect this very low uptake. 
Results from cytotoxicity assessments also showed that nanoparticles exhibiting a poorly negative or a poorly positive surface charge may exhibit the same cytotoxic profile than neutral nanoparticles. Indeed, $\mathrm{NP}(0), \mathrm{NP}(-)$ and $\mathrm{NP}(+)$ did not show a significant loss of membrane integrity but provided pro-inflammatory effect at high dose $(300 \mu \mathrm{g} / \mathrm{ml})$. No significant oxidative stress was detected which is consistent with a similar study carried out by Panas et al. where the same RAW264.7 macrophages were incubated with engineered silica nanoparticles of $25 \mathrm{~nm}$ diameter (Panas et al. 2013).

\section{Conclusion}

The present study clearly demonstrated that surface chemical functionalization plays a key role in the interactions between silica-based nanoparticles and cells with a significant impact on their uptake and biological in vitro toxicity. The highly positively charged nanoparticles were the most adsorbed at cell surface but were negligibly uptaken and triggered more cytotoxicity than other nanoparticles types. The highly negatively charged nanoparticle, were the most uptaken by cells and triggered cytotoxicity only at high dose. Neutrally charged nanoparticles and poorly, positively or negatively, charged nanoparticles expressed the same cytotoxic profile with a proinflammatory effect at high dose. Importantly, our findings suggest that nanoparticles adsorption at the cell membrane seems to play a more important role in cytotoxicity than nanoparticles uptake. Further investigations are needed to better understand how nanoparticle surface charge may impact biological responses in order to provide a "safer by design" approach for the engineering of new nano-objects. 
A. Kurtz-Chalot* - ADSORPTION AT CELL SURFACE AND CELLULAR UPTAKE OF SILICA NANOPARTICLES WITH DIFFERENT SURFACE CHEMICAL FUNCTIONALIZATIONS : IMPACT ON CYTOTOXICITY-
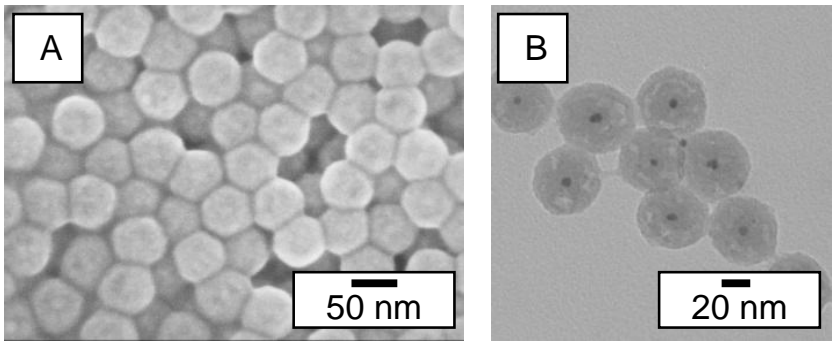

\section{Fig1}

Images of sterically stabilized silica nanoparticles

$\mathrm{NP}(0)$ by (A) Scanning electron microscopy and

(B) Transmission electron microscopy. 


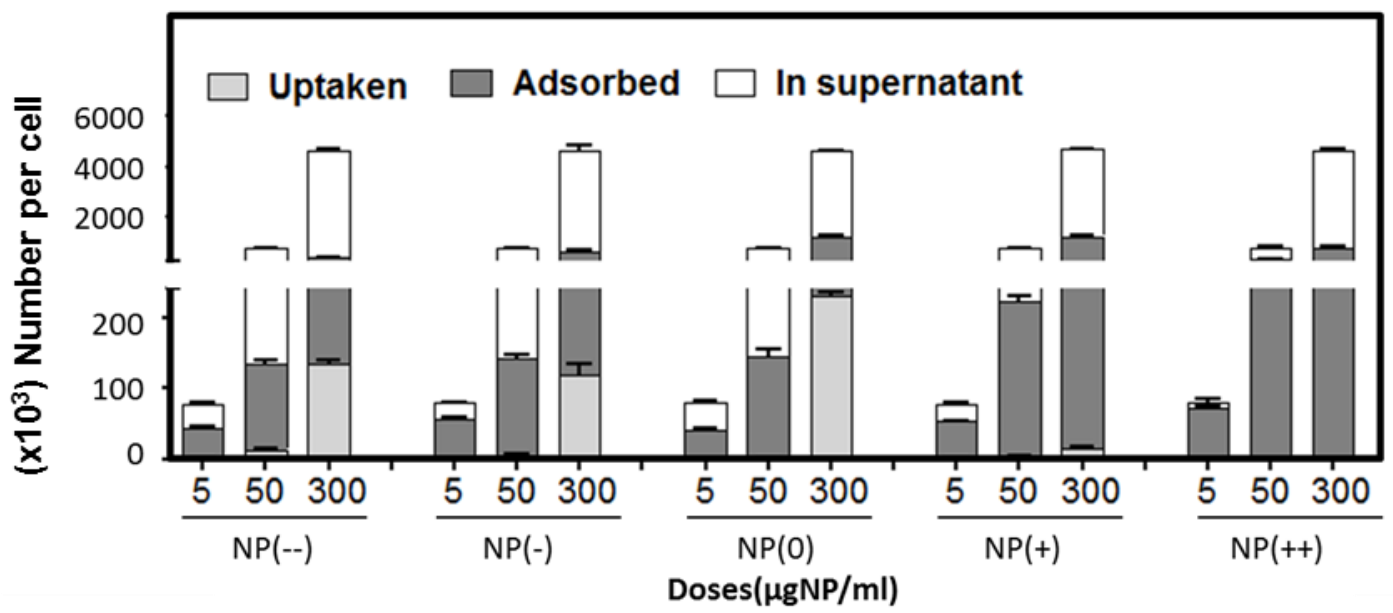

\begin{tabular}{|c|c|c|c|c|c|c|c|c|c|c|c|c|c|c|c|c|}
\hline & \multirow[b]{2}{*}{$\begin{array}{c}\text { Doses } \\
(\mu \mathrm{g} / \mathrm{ml})\end{array}$} & \multicolumn{3}{|c|}{ NP(--) } & \multicolumn{3}{|c|}{ NP(-) } & \multicolumn{3}{|c|}{$N P(0)$} & \multicolumn{3}{|c|}{$N P(+)$} & \multicolumn{3}{|c|}{$N P(++)$} \\
\hline & & 5 & 50 & 300 & 5 & 50 & 300 & 5 & 50 & 300 & 5 & 50 & 300 & 5 & 50 & 300 \\
\hline \multirow{3}{*}{$\%$} & $\begin{array}{c}\text { In } \\
\text { supernatant }\end{array}$ & 44 & 82 & 91 & 29 & 81 & 86 & 48 & 81 & 73 & 28 & 72 & 90 & 12 & 56 & 59 \\
\hline & Adsorbed & 56 & 15 & 6 & 71 & 17 & 11 & 52 & 18 & 22 & 70 & 26 & 9 & 98 & 44 & 41 \\
\hline & Uptaken & 0 & 3 & 3 & 0 & 2 & 3 & 0 & 1 & 5 & 2 & 2 & 1 & 0 & 0 & 0 \\
\hline
\end{tabular}

\section{Fig2}

Fluorescent (FITC) silica nanoparticles with different surface stabilizations: $N P(0), N P(+)$, $\mathrm{NP}(++), \mathrm{NP}(-)$ and $\mathrm{NP}(--)$ were incubated for $20 \mathrm{~h}$ with RAW264.7 macrophages and the distribution of NP was assessed by fluorimetry and Trypan Blue quenching. Results are presented as number of nanoparticles per cell. In order to facilitate the comprehension, the table gives the corresponding percentage referring to the total initial dose of NP in contact with cells. $(n=3)$. 

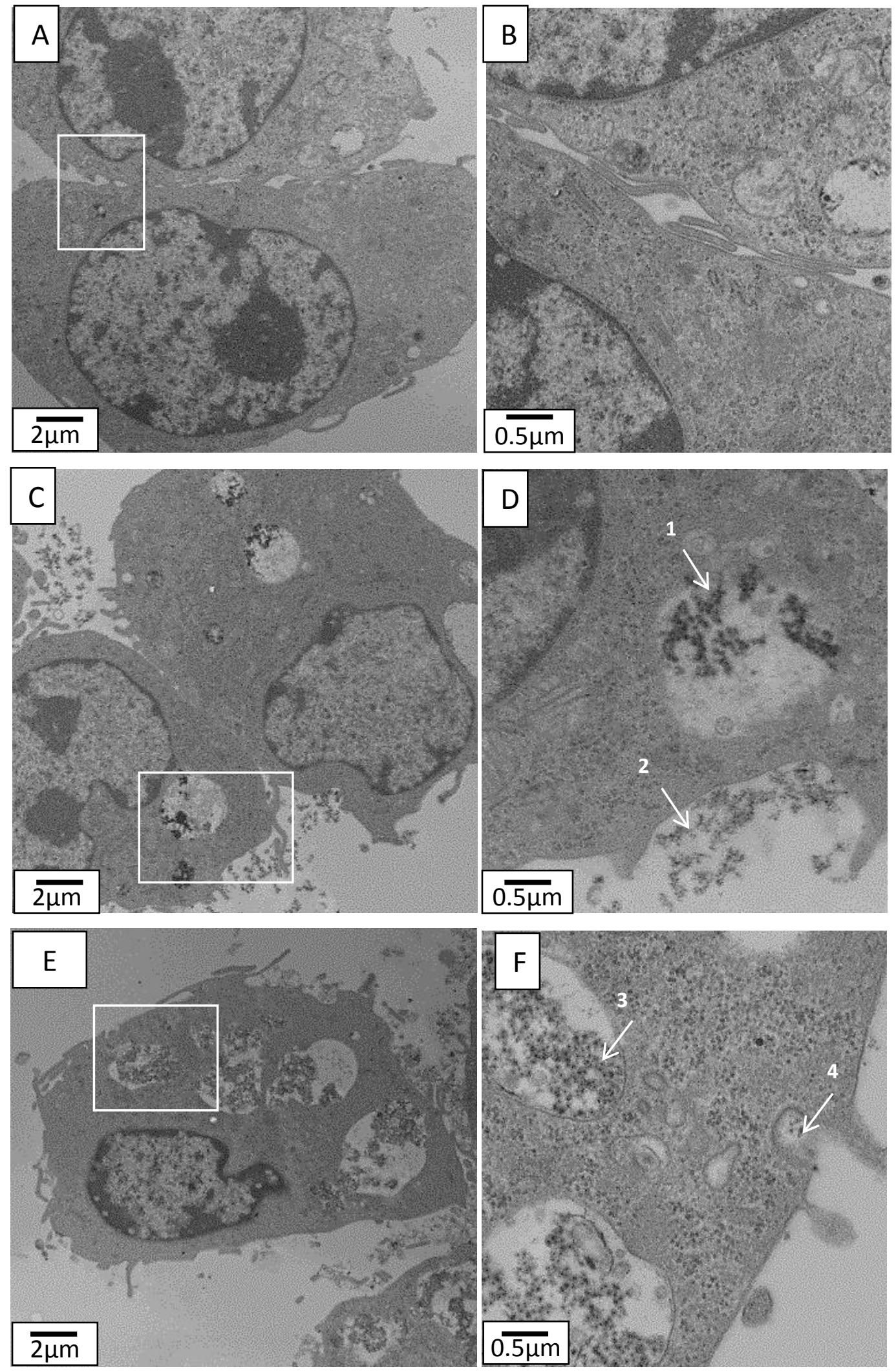
A. Kurtz-Chalot* - ADSORPTION AT CELL SURFACE AND CELLULAR UPTAKE OF SILICA NANOPARTICLES WITH

DIFFERENT SURFACE CHEMICAL FUNCTIONALIZATIONS : IMPACT ON CYTOTOXICITY-

\section{Fig3}

Cellular uptake of $\mathrm{NP}(0)$ and $\mathrm{NP}(++)$ by RAW 264.7 macrophages after a $20 \mathrm{~h}$ incubation $(300 \mu \mathrm{gNP} / \mathrm{ml})$ using transmission electron microscopy. (A) Control cell without nanoparticle. (B) Similar to the area within square of $(A)$. (C) Cell after incubation with nanoparticles NP(0). (D) Similar to the area within square of (C): (1) nanoparticles are in a vacuole and (2) nanoparticles are adhering to the cell membrane in a potential figure of phagocytosis pseudopodia. (E) Cell after incubation with nanoparticles $N P(++)$. (F) Similar to the area within square of $(E)$ : (3) nanoparticles are in a vacuole and (4) nanoparticles are adhering to the cell in a potential membrane figure of endocytosis. 
A. Kurtz-Chalot* - ADSORPTION AT CELL SURFACE AND CELLULAR UPTAKE OF SILICA NANOPARTICLES WITH DIFFERENT SURFACE CHEMICAL FUNCTIONALIZATIONS : IMPACT ON CYTOTOXICITY-
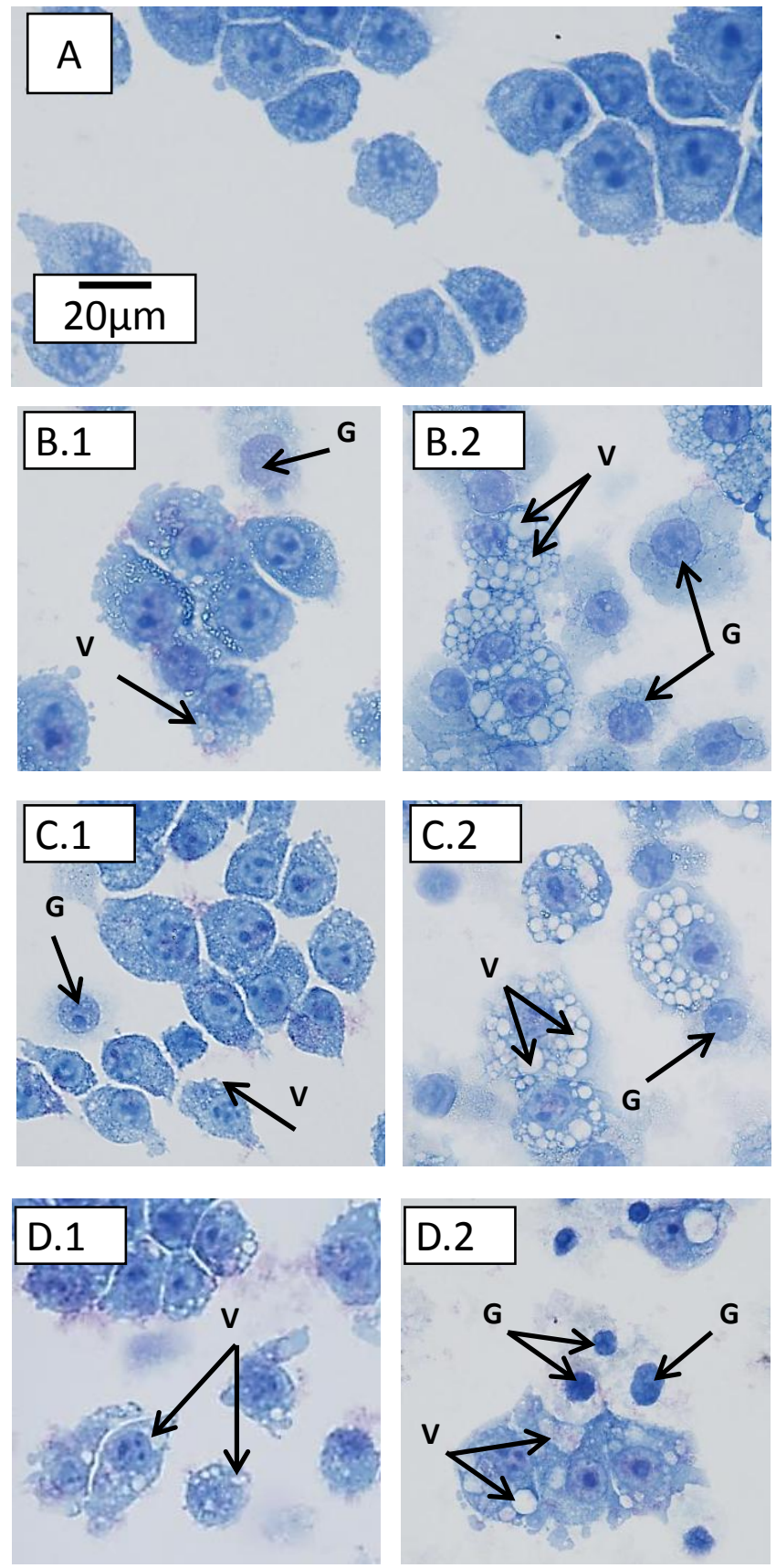

\section{Fig 4}

Morphology of macrophages observed after May Grünwald Giemsa staining (x600). (A) Control cells are macrophages incubated alone. (B), (C) and (D) images are macrophages incubated $20 \mathrm{~h}$ in presence of nanoparticles $\mathrm{NP}(--), \mathrm{NP}(0)$ and $\mathrm{NP}(++)$ respectively. Two different doses were used, 50 and $300 \mu \mathrm{g} / \mathrm{ml}$, corresponding to images (.1) and (.2) respectively. "G." mark ghost cells and "V." mark vacuoles. 
A. Kurtz-Chalot* - ADSORPTION AT CELL SURFACE AND CELLULAR UPTAKE OF SILICA NANOPARTICLES WITH DIFFERENT SURFACE CHEMICAL FUNCTIONALIZATIONS : IMPACT ON CYTOTOXICITY-

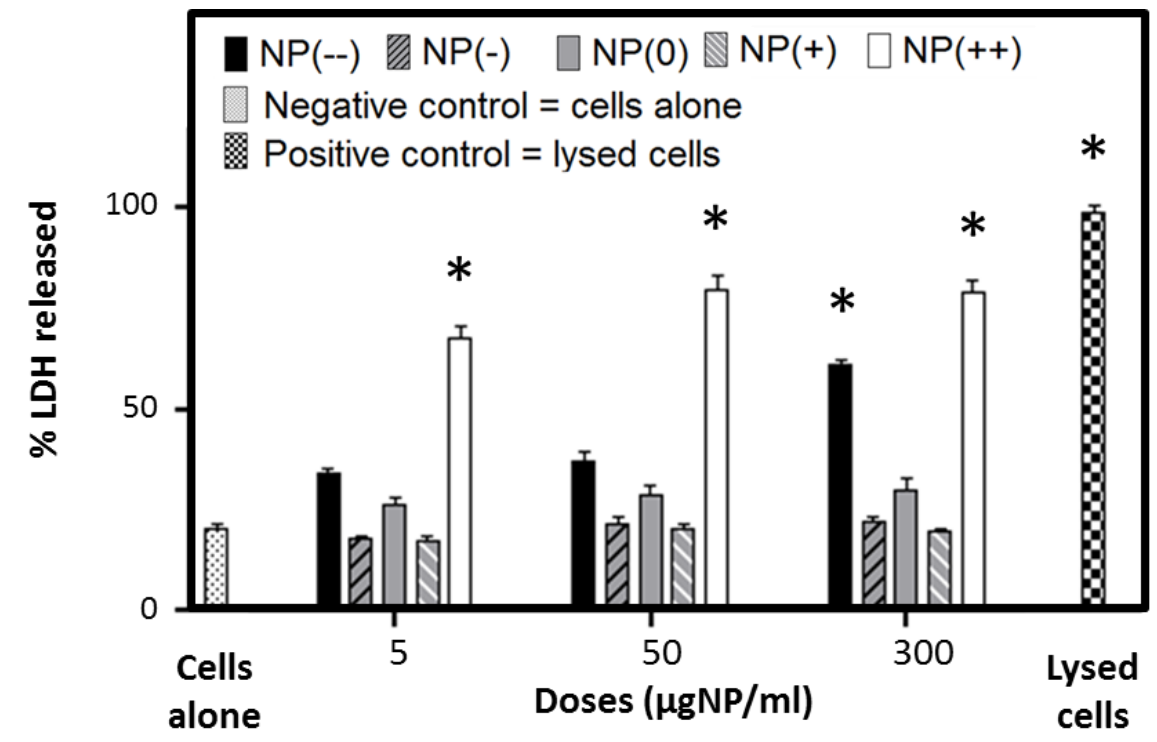

Fig5

Cytotoxicity of five different nanoparticles investigated using the LDH assay in RAW 264.7 macrophages. Data considered significant with $p<0.05$ are marked with an asterisk sign $\left(^{*}\right) .(n=3)$ 


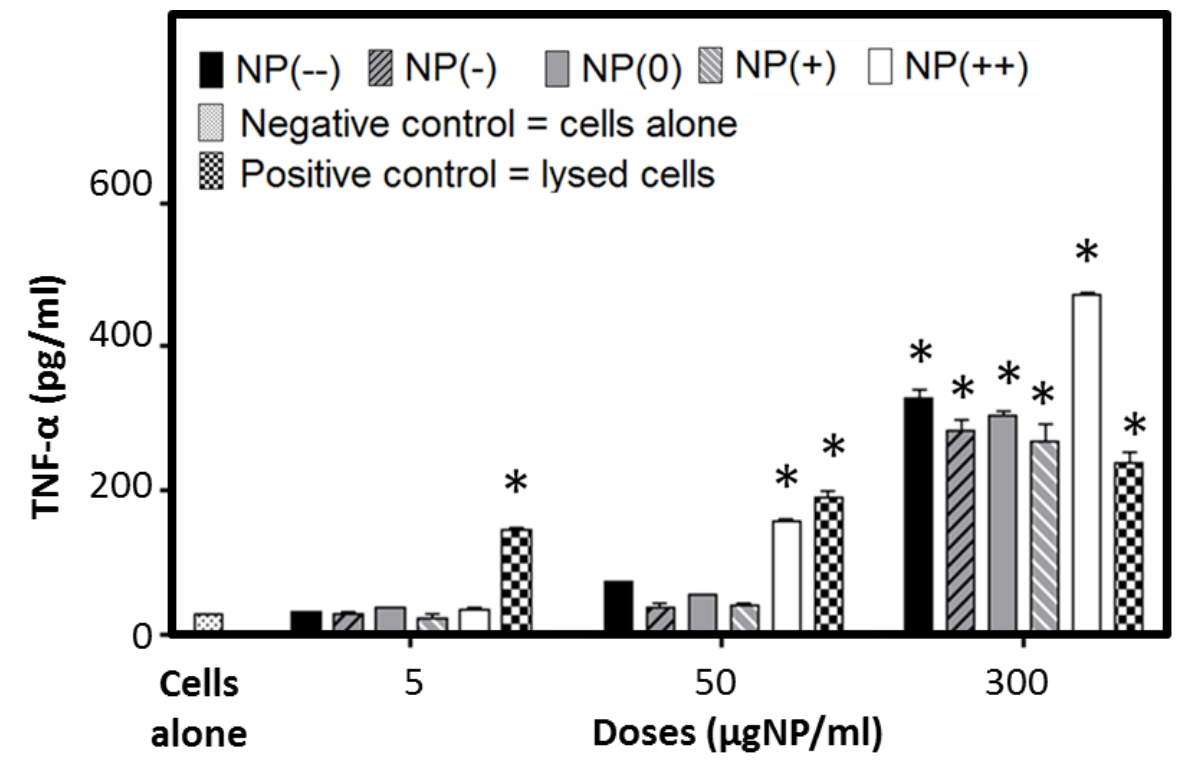

\section{Fig6}

Pro-inflammatory effect of five different nanoparticles investigated using the TNF- $\alpha$ assay in RAW 264.7 macrophages. Data considered significant with $p$ $<0.05$ are marked with an asterisk sign $\left(^{*}\right) .(n=3)$ 
A. Kurtz-Chalot* - ADSORPTION AT CELL SURFACE AND CELLULAR UPTAKE OF SILICA NANOPARTICLES WITH DIFFERENT SURFACE CHEMICAL FUNCTIONALIZATIONS : IMPACT ON CYTOTOXICITY-

Table 1 - Characteristics of the nanoparticles used in the present study.

\begin{tabular}{|c|c|c|c|c|c|c|}
\hline & $\begin{array}{l}\text { Function- } \\
\text { alization }\end{array}$ & $\begin{array}{c}\text { Zeta } \\
\text { potential } \\
\text { in water } \\
(\mathrm{pH} 7-8)\end{array}$ & $\begin{array}{c}\text { Zeta } \\
\text { potential } \\
\text { in DMEMc } \\
(\mathrm{pH} 7-8)\end{array}$ & $\begin{array}{l}\text { Geometric } \\
\text { diameter } \\
\text { (SEM) }\end{array}$ & $\begin{array}{l}\text { Hydro-dynamic } \\
\text { diameter (DLS) } \\
\text { in water }\end{array}$ & $\begin{array}{l}\text { Hydro- } \\
\text { dynamic } \\
\text { diameter } \\
\text { (DLS) } \\
\text { in DMEMc }\end{array}$ \\
\hline NP (--) & $\mathrm{Si}-\mathrm{COOH}$ & $-30 \mathrm{mV}$ & $-96 m V$ & $52 \pm 2 \mathrm{~nm}$ & $82 \pm 1 \mathrm{~nm}$ & $104 \pm 4 \mathrm{~nm}$ \\
\hline NP(-) & $\mathrm{Si}-\mathrm{COOH}$ & $-25 \mathrm{mV}$ & $-13 \mathrm{mV}$ & $50 \pm 5 \mathrm{~nm}$ & $62 \pm 5 \mathrm{~nm}$ & $85 \pm 3 \mathrm{~nm}$ \\
\hline NP (0) & $\begin{array}{c}\text { Si- } \\
\text { PEG200 }\end{array}$ & $0 \mathrm{mV}$ & $-11 \mathrm{mV}$ & $52 \pm 3 \mathrm{~nm}$ & $76 \pm 7 \mathrm{~nm}$ & $88 \pm 5 \mathrm{~nm}$ \\
\hline $\mathrm{NP}(+)$ & $\begin{array}{l}\text { Si- } \\
\mathrm{NH}_{2}\end{array}$ & $5 \mathrm{mV}$ & $-20 \mathrm{mV}$ & $62 \pm 2 \mathrm{~nm}$ & $75 \pm 5 \mathrm{~nm}$ & $90 \pm 5 \mathrm{~nm}$ \\
\hline NP (++) & $\begin{array}{l}\mathrm{Si}- \\
\mathrm{NH}_{2}\end{array}$ & $12 \mathrm{mV}$ & $-94 \mathrm{mV}$ & $66 \pm 7 \mathrm{~nm}$ & $89 \pm 2 \mathrm{~nm}$ & $111 \pm 10 \mathrm{~nm}$ \\
\hline
\end{tabular}


A. Kurtz-Chalot* - ADSORPTION AT CELL SURFACE AND CELLULAR UPTAKE OF SILICA NANOPARTICLES WITH DIFFERENT SURFACE CHEMICAL FUNCTIONALIZATIONS : IMPACT ON CYTOTOXICITY-

Table 2 - Evolution of cell morphology after incubation with $\mathrm{NP}(--), \mathrm{NP}(0)$ and $\mathrm{NP}(++)$ at 50 or $300 \mu \mathrm{g} / \mathrm{ml}$ : macrophages initially have a normal morphology with homogeneous cytoplasm. Activated macrophages cytoplasm contains vacuoles, and then close to death, cell without defined cytoplasm but a condensed nucleus and a lysed membrane are called "ghost". $100 \%$ of control cells exhibit a normal morphology.

\begin{tabular}{|c|c|c|c|}
\hline $\begin{array}{c}\text { Cell morphology } \\
\text { evolution depending } \\
\text { on type and dose of } \\
\text { nanoparticles }\end{array}$ & NP(--) & $N P(0)$ & $N P(++)$ \\
\hline & $86 \%$ normal & $96 \%$ normal & $17 \%$ normal \\
\hline \multirow[t]{3}{*}{$50 \mu \mathrm{g} / \mathrm{ml}$} & $9 \%$ activated & $1 \%$ activated & $79 \%$ activated \\
\hline & $5 \%$ ghost & $3 \%$ ghost & $4 \%$ ghost \\
\hline & $63 \%$ normal & $12 \%$ normal & $4 \%$ normal \\
\hline \multirow[t]{2}{*}{$300 \mu \mathrm{g} / \mathrm{ml}$} & $32 \%$ activated & $58 \%$ activated & $19 \%$ activated \\
\hline & $5 \%$ ghost & $16 \%$ ghost & $77 \%$ ghost \\
\hline
\end{tabular}




\section{ACKNOWLEDGEMENT}

The authors would like to acknowledge the financial support of the Région Rhône-Alpes and the Conseil Général de la Loire.

\section{REFERENCES}

ISO - International Organization for Standardization, 2012, ISO/TR 13014:2012 Nanotechnologies - Guidance on physico-chemical characterization of engineered nanoscale materials for toxicologic assessment. Available at: http://www.iso.org/iso/home/store/catalogue_tc/catalogue_detail.htm?csnumber=52334

Albanese, A., Tang, P.S., and Chan, W.C.W. (2012). The effect of nanoparticle size, shape, and surface chemistry on biological systems. Annu Rev Biomed Eng 14, 1-16.

Van Amersfoort, E.S., and Van Strijp, J.A. (1994). Evaluation of a flow cytometric fluorescence quenching assay of phagocytosis of sensitized sheep erythrocytes by polymorphonuclear leukocytes. Cytometry 17, 294-301.

Auffinger, B., Morshed, R., Tobias, A., Cheng, Y., Ahmed, A.U., and Lesniak, M.S. (2013). Drugloaded nanoparticle systems and adult stem cells: a potential marriage for the treatment of malignant glioma? Oncotarget 4, 378-396.

Benezra, M., Penate-Medina, O., Zanzonico, P.B., Schaer, D., Ow, H., Burns, A., DeStanchina, E., Longo, V., Herz, E., Iyer, S., et al. (2011). Multimodal silica nanoparticles are effective cancertargeted probes in a model of human melanoma. J Clin Invest 121, 2768-2780.

Bhattacharjee, S., de Haan, L.H.J., Evers, N.M., Jiang, X., Marcelis, A.T.M., Zuilhof, H., Rietjens, I.M.C.M., and Alink, G.M. (2010). Role of surface charge and oxidative stress in cytotoxicity of organic monolayer-coated silicon nanoparticles towards macrophage NR8383 cells. Part Fibre Toxicol 7, 25.

Bruch, J., Rehn, S., Rehn, B., Borm, P.J.A., and Fubini, B. (2004). Variation of biological responses to different respirable quartz flours determined by a vector model. Int J Hyg Environ Health 207, 203-216.

Cedervall, T., Lynch, I., Lindman, S., Berggård, T., Thulin, E., Nilsson, H., Dawson, K.A., and Linse, S. (2007). Understanding the nanoparticle-protein corona using methods to quantify exchange rates and affinities of proteins for nanoparticles. Proc. Natl. Acad. Sci. U.S.A. 104, 2050-2055. 
Chandolu, V., and Dass, C.R. (2013). Treatment of lung cancer using nanoparticle drug delivery systems. Curr Drug Discov Technol 10, 170-176.

Chung, T.-H., Wu, S.-H., Yao, M., Lu, C.-W., Lin, Y.-S., Hung, Y., Mou, C.-Y., Chen, Y.-C., and Huang, D.-M. (2007). The effect of surface charge on the uptake and biological function of mesoporous silica nanoparticles in 3T3-L1 cells and human mesenchymal stem cells. Biomaterials 28, 2959-2966.

Colilla, M., Manzano, M., and Vallet-Regí, M. (2008). Recent advances in ceramic implants as drug delivery systems for biomedical applications. Int J Nanomedicine 3, 403-414.

Dausend, J., Musyanovych, A., Dass, M., Walther, P., Schrezenmeier, H., Landfester, K., and Mailänder, V. (2008). Uptake mechanism of oppositely charged fluorescent nanoparticles in HeLa cells. Macromol Biosci 8, 1135-1143.

Dell'Orco, D., Lundqvist, M., Oslakovic, C., Cedervall, T., and Linse, S. (2010). Modeling the time evolution of the nanoparticle-protein corona in a body fluid. PLoS ONE 5, e10949.

DeLoid, G., Cohen, J.M., Darrah, T., Derk, R., Rojanasakul, L., Pyrgiotakis, G., Wohlleben, W., and Demokritou, P. (2014). Estimating the effective density of engineered nanomaterials for in vitro dosimetry. Nat Commun 5.

Duffin, R., Mills, N.L., and Donaldson, K. (2007). Nanoparticles-a thoracic toxicology perspective. Yonsei Med. J. 48, 561-572.

El Badawy, A.M., Silva, R.G., Morris, B., Scheckel, K.G., Suidan, M.T., and Tolaymat, T.M. (2011a). Surface Charge-Dependent Toxicity of Silver Nanoparticles. Environ. Sci. Technol. 45, 283-287.

El Badawy, A.M., Silva, R.G., Morris, B., Scheckel, K.G., Suidan, M.T., and Tolaymat, T.M. (2011b). Surface charge-dependent toxicity of silver nanoparticles. Environ. Sci. Technol. 45, 283-287.

Faunce, T.A., White, J., and Matthaei, K.I. (2008). Integrated research into the nanoparticleprotein corona: a new focus for safe, sustainable and equitable development of nanomedicines. Nanomedicine (Lond) 3, 859-866.

Frohlich, E. (2012). The role of surface charge in cellular uptake and cytotoxicity of medical nanoparticles. Int J Nanomedicine 7, 5577-5591.

Fubini, B., Fenoglio, I., Ceschino, R., Ghiazza, M., Martra, G., Tomatis, M., Borm, P., Schins, R., and Bruch, J. (2004). Relationship between the state of the surface of four commercial quartz flours and their biological activity in vitro and in vivo. Int J Hyg Environ Health 207, 89-104. 
Ge, Y., Zhang, Y., Xia, J., Ma, M., He, S., Nie, F., and Gu, N. (2009). Effect of surface charge and agglomerate degree of magnetic iron oxide nanoparticles on KB cellular uptake in vitro. Colloids and Surfaces B: Biointerfaces 73, 294-301.

Graf, C., Gao, Q., Schütz, I., Noufele, C.N., Ruan, W., Posselt, U., Korotianskiy, E., Nordmeyer, D., Rancan, F., Hadam, S., et al. (2012). Surface functionalization of silica nanoparticles supports colloidal stability in physiological media and facilitates internalization in cells. Langmuir 28, 7598-7613.

Gratton, S.E.A., Ropp, P.A., Pohlhaus, P.D., Luft, J.C., Madden, V.J., Napier, M.E., and DeSimone, J.M. (2008). The effect of particle design on cellular internalization pathways. Proc Natl Acad Sci U S A 105, 11613-11618.

Greish, K., Thiagarajan, G., Herd, H., Price, R., Bauer, H., Hubbard, D., Burckle, A., Sadekar, S., Yu, T., Anwar, A., et al. (2011). Size and surface charge significantly influence the toxicity of silica and dendritic nanoparticles. Nanotoxicology.

Guarnieri, D., Malvindi, M.A., Belli, V., Pompa, P.P., and Netti, P. (2014). Effect of silica nanoparticles with variable size and surface functionalization on human endothelial cell viability and angiogenic activity. J Nanopart Res 16, 1-14.

Hu, Y., Xie, J., Tong, Y.W., and Wang, C.-H. (2007). Effect of PEG conformation and particle size on the cellular uptake efficiency of nanoparticles with the HepG2 cells. Journal of Controlled Release 118, 7-17.

Huang, D.-M., Hung, Y., Ko, B.-S., Hsu, S.-C., Chen, W.-H., Chien, C.-L., Tsai, C.-P., Kuo, C.-T., Kang, J.-C., Yang, C.-S., et al. (2005). Highly efficient cellular labeling of mesoporous nanoparticles in human mesenchymal stem cells: implication for stem cell tracking. FASEB J. 19, 2014-2016.

Landsiedel, R., Ma-Hock, L., Hofmann, T., Wiemann, M., Strauss, V., Treumann, S., Wohlleben, W., Gröters, S., Wiench, K., and Ravenzwaay, B. van (2014). Application of short-term inhalation studies to assess the inhalation toxicity of nanomaterials. Particle and Fibre Toxicology 11, 16.

Lankoff, A., Arabski, M., Wegierek-Ciuk, A., Kruszewski, M., Lisowska, H., Banasik-Nowak, A., Rozga-Wijas, K., Wojewodzka, M., and Slomkowski, S. (2013). Effect of surface modification of silica nanoparticles on toxicity and cellular uptake by human peripheral blood lymphocytes in vitro. Nanotoxicology 7, 235-250.

Leclerc, L., Boudard, D., Pourchez, J., Forest, V., Sabido, O., Bin, V., Palle, S., Grosseau, P., Bernache, D., and Cottier, M. (2010). Quantification of microsized fluorescent particles phagocytosis to a better knowledge of toxicity mechanisms. Inhal Toxicol 22, 1091-1100. 
Leclerc, L., Boudard, D., Pourchez, J., Forest, V., Marmuse, L., Louis, C., Bin, V., Palle, S., Grosseau, P., Bernache-Assollant, D., et al. (2012a). Quantitative cellular uptake of double fluorescent core-shelled model submicronic particles. J Nanopart Res 14, 1-13.

Leclerc, L., Rima, W., Boudard, D., Pourchez, J., Forest, V., Bin, V., Mowat, P., Perriat, P., Tillement, O., Grosseau, P., et al. (2012b). Size of submicrometric and nanometric particles affect cellular uptake and biological activity of macrophages in vitro. Inhal Toxicol 24, 580-588.

Lidén, G. (2011). The European commission tries to define nanomaterials. Ann Occup Hyg 55, 15.

Lundqvist, M., Stigler, J., Elia, G., Lynch, I., Cedervall, T., and Dawson, K.A. (2008). Nanoparticle size and surface properties determine the protein corona with possible implications for biological impacts. PNAS 105, 14265-14270.

Luzio, J.P., Poupon, V., Lindsay, M.R., Mullock, B.M., Piper, R.C., and Pryor, P.R. (2003). Membrane dynamics and the biogenesis of lysosomes. Mol. Membr. Biol. 20, 141-154.

Martini, M., Perriat, P., Montagna, M., Pansu, R., Julien, C., Tillement, O., and Roux, S. (2009). How Gold Particles Suppress Concentration Quenching of Fluorophores Encapsulated in Silica Beads. J. Phys. Chem. C 113, 17669-17677.

Mignot, A., Truillet, C., Lux, F., Sancey, L., Louis, C., Denat, F., Boschetti, F., Bocher, L., Gloter, A., Stéphan, O., et al. (2013). A top-down synthesis route to ultrasmall multifunctional Gd-based silica nanoparticles for theranostic applications. Chemistry 19, 6122-6136.

Munkholm, C., Parkinson, D.R., and Walt, D.R. (1990). Intramolecular fluorescence selfquenching of fluoresceinamine. J. Am. Chem. Soc. 112, 2608-2612.

Mura, S., Hillaireau, H., Nicolas, J., Le Droumaguet, B., Gueutin, C., Zanna, S., Tsapis, N., and Fattal, E. (2011). Influence of surface charge on the potential toxicity of PLGA nanoparticles towards Calu-3 cells. Int J Nanomedicine 6, 2591-2605.

Musyanovych, A., Dausend, J., Dass, M., Walther, P., Mailänder, V., and Landfester, K. (2011). Criteria impacting the cellular uptake of nanoparticles: A study emphasizing polymer type and surfactant effects. Acta Biomaterialia 7, 4160-4168.

Nabeshi, H., Yoshikawa, T., Arimori, A., Yoshida, T., Tochigi, S., Hirai, T., Akase, T., Nagano, K., Abe, Y., Kamada, H., et al. (2011). Effect of surface properties of silica nanoparticles on their cytotoxicity and cellular distribution in murine macrophages. Nanoscale Research Letters 6, 93.

Napierska, D., Thomassen, L.C., Lison, D., Martens, J.A., and Hoet, P.H. (2010). The nanosilica hazard: another variable entity. Particle and Fibre Toxicology 7, 39. 
Nuutila, J., and Lilius, E.-M. (2005). Flow cytometric quantitative determination of ingestion by phagocytes needs the distinguishing of overlapping populations of binding and ingesting cells. Cytometry A 65, 93-102.

Ohkuma, S., and Poole, B. (1978). Fluorescence probe measurement of the intralysosomal pH in living cells and the perturbation of $\mathrm{pH}$ by various agents. Proc Natl Acad Sci U S A 75, 33273331.

Panas, A., Marquardt, C., Nalcaci, O., Bockhorn, H., Baumann, W., Paur, H.-R., Mülhopt, S., Diabaté, S., and Weiss, C. (2013). Screening of different metal oxide nanoparticles reveals selective toxicity and inflammatory potential of silica nanoparticles in lung epithelial cells and macrophages. Nanotoxicology 7, 259-273.

Qiu, Y., Liu, Y., Wang, L., Xu, L., Bai, R., Ji, Y., Wu, X., Zhao, Y., Li, Y., and Chen, C. (2010). Surface chemistry and aspect ratio mediated cellular uptake of Au nanorods. Biomaterials 31, 76067619.

Rancan, F., Gao, Q., Graf, C., Troppens, S., Hadam, S., Hackbarth, S., Kembuan, C., BlumePeytavi, U., Rühl, E., Lademann, J., et al. (2012). Skin Penetration and Cellular Uptake of Amorphous Silica Nanoparticles with Variable Size, Surface Functionalization, and Colloidal Stability. ACS Nano 6, 6829-6842.

Riehemann, K., Schneider, S.W., Luger, T.A., Godin, B., Ferrari, M., and Fuchs, H. (2009). Nanomedicine--challenge and perspectives. Angew. Chem. Int. Ed. Engl. 48, 872-897.

Seaton, A., and Donaldson, K. (12). Nanoscience, nanotoxicology, and the need to think small. The Lancet 365, 923-924.

Slowing, I.I., Vivero-Escoto, J.L., Wu, C.-W., and Lin, V.S.-Y. (2008). Mesoporous silica nanoparticles as controlled release drug delivery and gene transfection carriers. Adv. Drug Deliv. Rev. 60, 1278-1288.

Sohaebuddin, S.K., Thevenot, P.T., Baker, D., Eaton, J.W., and Tang, L. (2010). Nanomaterial cytotoxicity is composition, size, and cell type dependent. Part Fibre Toxicol 7, 22.

Tenzer, S., Docter, D., Kuharev, J., Musyanovych, A., Fetz, V., Hecht, R., Schlenk, F., Fischer, D., Kiouptsi, K., Reinhardt, C., et al. (2013). Rapid formation of plasma protein corona critically affects nanoparticle pathophysiology. Nat Nanotechnol 8, 772-781.

Vallet-Regi, M., and Balas, F. (2008). Silica Materials for Medical Applications. Open Biomed Eng J 2, 1-9. 
Walkey, C.D., and Chan, W.C.W. (2012). Understanding and controlling the interaction of nanomaterials with proteins in a physiological environment. Chem Soc Rev 41, 2780-2799.

Walkey, C.D., Olsen, J.B., Guo, H., Emili, A., and Chan, W.C.W. (2012). Nanoparticle size and surface chemistry determine serum protein adsorption and macrophage uptake. J. Am. Chem. Soc. 134, 2139-2147.

Yu, T., Malugin, A., and Ghandehari, H. (2011). Impact of silica nanoparticle design on cellular toxicity and hemolytic activity. ACS Nano 5, 5717-5728.

Yue, Z.-G., Wei, W., Lv, P.-P., Yue, H., Wang, L.-Y., Su, Z.-G., and Ma, G.-H. (2011). Surface charge affects cellular uptake and intracellular trafficking of chitosan-based nanoparticles. Biomacromolecules 12, 2440-2446. 